\title{
KOSULYS IR RŪKYMAS
}

\author{
DR. KRISTINA STRAVINSKAITE்
}

KMU PULMONOLOGIJOS IR IMUNOLOGIJOS KLINIKA

Reikšminiai žodžiai: kosulys, kosulio reflekso jautrumas, rūkymas, LOPL.

Santrauka. Kosulys - svarbus kvejpavimo sistemos apsauginis refleksas. Kosuliu skundžiasi 9-33 proc. Europos ir JAV gyventojų. Kosulys yra vienas dažniausių simptomų, dèl kurių pacientai kreipiasi į gydytoją. Vaistams nuo kosulio, nepaisant jų dalinio efektyvumo, išleidžiama šimtai milijardų dolerių. Taigi kosulio problema aktuali ne tik medicininiu, bet ir socialiniu bei ekonominiu požiūriu. Rūkymas yra vienas svarbiausių išvengiamų kvėpavimo ligų rizikos veiksnių. Rūkymas sumažina sveikų asmenழ̨ kosulio reflekso jautrumą, bet jis normalizuojasi jiems metus rūkyti. Sergančių LOPL rūkorių ir sergančių LOPL buvusių rūkorių kosulio reflekso jautrumas nesiskiria.

Kosulys yra svarbus kvėpavimo sistemos apsauginis refleksas. Kosint iš kvėpavimo takų pašalinama dèl sustiprejjusios gamybos ar sutrikusio mukociliarinio klirenso pagausėjęs kvẻpavimo takų sekretas, ikvejptos dalelès, žalingos medžiagos, mikroorganizmai, svetimkūniai. Kosulio refleksas būna susilpnèjęs vyresniems asmenims, naujagimiams, ligoniams po plaučiu transplantacijos, sergantiesiems nervų ir raumenų ligomis, esant paralyžiui, anestezijos metu. Susilpnejjus kosulio apsauginei funkcijai, dideja aspiracijos ir kvèpavimo taku infekcijos rizika. Tačiau sergant kai kuriomis ligomis, pavyzdžiui, astma, LOPL, gastroezofaginio refliukso liga (GERL), viršutinių kvėpavimo takų sindromu, kosulys būna sustiprèjęs, neproduktyvus, užsitęsęs ir netgi gali būti žalingas kvėpavimo taku gleivinei. Toks kosulys blogina pacientu gyvenimo kokybę, gali sukelti įvairias komplikacijas ir priverčia pacientą kreiptis ì gydytoją.

\section{KOSULIO PAPLITIMAS}

Kosuliu skundžiasi 9-33 proc. Europos ir JAV gyventojų. Europos respiratologų sąjungos (ERS) iniciatyva atliktas tyrimas, kuriame dalyvavo 18277 asmenys nuo 20 iki 48 metų iš 16 Europos šalių, rodo, kad naktiniu kosuliu skundžiasi 30 proc., produktyviu - 10 proc., neproduktyviu - 10 proc. tiriamụjų. Nèra tikslių duomenų apie kosulio paplitimą Lietuvoje, tačiau atsitiktinès atrankos būdu ištyrus penkių Lietuvos rajonų gyventojus buvo nustatyta, kad kosuliu skundžiasi 17 proc. nerūkančiụjų, 18 proc. metusiųjų rūkyti ir 32 proc. rūkorių (1 pav.). Kosulio paplitimas kai kuriose Europos šalyse ir JAV pateiktas 1 lentelëje.

Kosulys yra vienas dažniausių simptomų, dèl kurių pacientai kreipiasi ì gydytoją. JAV dèl kosulio per metus pas gydytoją apsilankoma apie trys milijonus kartų. I šeimos gydytoją dažniausiai kreipiasi pacientai, varginami ūminio kosulio, kuris lydi peršalimo ligas. Lètiniu kosuliu besiskundžiantys pacientai sudaro 10-38 proc. visų ambulatorinių pacientų, kurie kreipiasi i̇ gydytoją pulmonologą.

Vaistams nuo kosulio, nepaisant jų dalinio efektyvumo, Didžiojoje Britanijoje išleidžiama šimtai milijonai svarų sterlingų, o JAV keletas milijardų dolerių (2 lentelè). Tačiau šie duomenys neatspindi tikrųjų kosulio gydymo išlaidų, nes neịskaičiuoti vaistai peršalimo ligoms ir lètinam kosuliui gydyti.

Taigi kosulio problema aktuali ne tik medicininiu, bet ir socialiniu bei ekonominiu požiūriu.

Lètinio kosulio priežasčių yra labai daug, tačiau dažniausios, kurios sudaro apie 90 proc. visų yra astma, gastroezofaginio refliukso liga ir viršutinių kvẻpavimo takų sindromas. Lètinio kosulio priežastị pavyksta nustatyti nuo 75 iki 90 proc. atvejų. Tačiau patogeneziniai lètinio kosulio mechanizmai nèra visiškai aiškūs. Kosulio ir jo reflekso jautrumo tyrimų dar nèra atlikta pakankamai, kad būtų atsakyta ị svarbiausius klausimus. Pasaulyje yra tik keletas medicinos mokslo centrų, atliekančių kosulio ir jo reflekso jautrumo tyrimus.

\section{RŪKYMO PAPLITIMAS}

Rūkymas yra vienas svarbiausių išvengiamų kvėpavimo ligų rizikos veiksnių. Rūkymas yra pagrindinis lètinę obstrukcinę plaučių ligą (LOPL) lemiantis veiksnys. Jis taip pat lemia apie 90 proc. plaučių vėžio atvejų. Sergamumas su rūkymu susijusiomis kvejpavimo orga- 
1 lentelè. KOSULIO PAPLITIMAS IVAIRIOSE ŠALYSE

\begin{tabular}{|c|c|c|}
\hline Šalis & Imtis & Paplitimas (proc.) \\
\hline Lietuva & 1633 & $\begin{array}{l}17 \text { - nerūkančiųjų } \\
18 \text { - metusiųjų rūkyti } \\
32 \text { - rūkančiųjų }\end{array}$ \\
\hline Šiaurès Švedija & 6610 & 11 \\
\hline Pietryčių Anglija & 9077 & 16 \\
\hline Šiaurès Anglija & 4003 & 12 \\
\hline Italija & 18000 & 11,9 \\
\hline Švedija & 623 & $\begin{array}{l}11 \text { - neproduktyvus kosulys } \\
8 \text { - produktyvus kosulys } \\
38 \text { - naktinis kosulys }\end{array}$ \\
\hline Šveicarija & 9651 & $\begin{array}{l}9,2 \text { - rūkoriụ } \\
3,3 \text { - niekada nerūkiusiųjų }\end{array}$ \\
\hline JAV & 1109 & 18 \\
\hline JAV (tik baltieji) & 5743 & 9,3 \\
\hline
\end{tabular}

nų ligomis kasmet dideja. Lietuvoje kasdien rūko apie 24,5 proc. gyventojų (2 pav.). Vyrų Lietuvoje rūko 42,1 proc., o moterų - 9,8 proc., rūkančių vyrų skaičius nuo 2000 metú mažejja, o moterų - didejja.

Rūkymas kiekvienam asmeniui pažeidžia plaučius, tačiau skiriasi pažeidimo dydis ir sunkumas. Apie 30 proc. rūkorių kvépavimo takų simptomai nepasireiškia, jų kvèpavimo funkcija normali, apie 50 proc. rūkorių būdingi lètiniai kvépavimo taku simptomai be kvépavimo taku obstrukcijos, o 15-20 proc. rūkorių suserga LOPL.

\section{RŪKYMO İTAKA KOSULIO REFLEKSO JAUTRUMUI}

Rūkoriai, ypač tie, kurie rūko daug - daugiau nei 20 cigarečių per dieną, triskart dažniau skundžiasi kosuliu nei nerūkantys asmenys. Metusieji rūkyti kosuliu skundžiasi taip pat kaip ir nerūkantieji (3 lentelè). Nustatyta, kad didejant surūkyto tabako kiekiui per dieną didèja naktinio ir neproduktyvaus kosulio rizika, o didejant pasyvaus rūkymo laikui - didejja produktyvaus kosulio rizika.

Nustatyta, kad rūkymas sumažina sveikų asmenų kosulio reflekso jautrumą, tačiau šio sumažejimo mechanizmai nèra aiškūs. Manoma, kad ilgalaikis tabako dūmų poveikis sumažina kosulio receptorių jautrumą. Ši hipotezè galètų paaiškinti, kodèl metus rūkyti trumpam laikui
2 lentelè. IŠLAIDOS NERECEPTINIAMS VAISTAMS NUO KOSULIO IR PERŠALIMO

\begin{tabular}{lc}
\hline Vaistai nuo kosulio & Išlaidos (milijonais) \\
\hline Jungtinė Karalystė & \\
vaistai nuo peršalimo ir gripo & $£ 99,3$ \\
sirupas nuo kosulio & $£ 92,5$ \\
vaistai nuo gerklès skausmo & $£ 86,7$ \\
dekongestantai ị nosị & $£ 50,5$ \\
\hline Jungtinès Amerikos Valstijos & \\
vaistai nuo peršalimo ir gripo & $\$ 1145$ \\
vaistai sinusitui gydyti & $\$ 331$ \\
dekongestantai ị nosị & $\$ 169$ \\
mikstūros nuo kosulio & $\$ 328$ \\
lašai nuo kosulio & $\$ 247$ \\
vaistai nuo gerklès skausmo & $\$ 79$ \\
tepalai krūtinei trinti & $\$ 40$ \\
\hline
\end{tabular}

sustiprëja kosulys. Kita prielaida, kodèl rūkant sumažèja kosulio reflekso jautrumas, susijusi su padidejusia gleiviu sekrecija. Gleivès sudaro paviršinį barjerą, trukdantị kosulị sukeliančioms medžiagoms pasiekti kosulio receptorius. Negalima atmesti hipotezès, kad sveikų rūkorių kosulio reflekso jautrumas sumažèja ne dèl tabako dūmų poveikio, o dèl to, kad rūkorių natūralus kosulio reflekso jautrumas yra mažesnis ir jie toleruoja tabako dūmus.

Kosulys yra svarbus apsauginis kvėpavimo sistemos refleksas, todèl sumažejęs jo jautrumo yra kliniškai svarbus. Rūkoriams didejja virusinès ir bakterinès kvėpavimo taku infekcijos rizika. Padidejja aspiracinès pneumonijos rizika vyresniems ar insultu sergantiems asmenims. Cigarečių dūmai pažeidžia mukociliarinị aparatą, todèl pablogèja gleivių atkosejjimas. Kosulys yra dažnas LOPL simptomas, tačiau tyrimų kosulio reflekso pokyčius sergant LOPL ịvertinti atlikta tik keletas. Ju duomenys prieštaringi: vieni tyrejjai nustatè, kad sergančiųjų LOPL kosulio reflekso jautrumas yra didesnis už sveikų asmenų, kiti skirtumų tarp sergančiųjų LOPL ir sveikų asmenų kosulio jautrumo nenustatè.

\section{KOSULIO REFLEKSO JAUTRUMO POKYČIAI METUS RŪKYTI}

Metusiems rūkyti sveikiems ir sergantiems LOPL asmenims sumažèja kvėpavimo takų simptomai ir léčiau mažèja FEV1. Tačiau kvėpavimo takų uždegimas me-

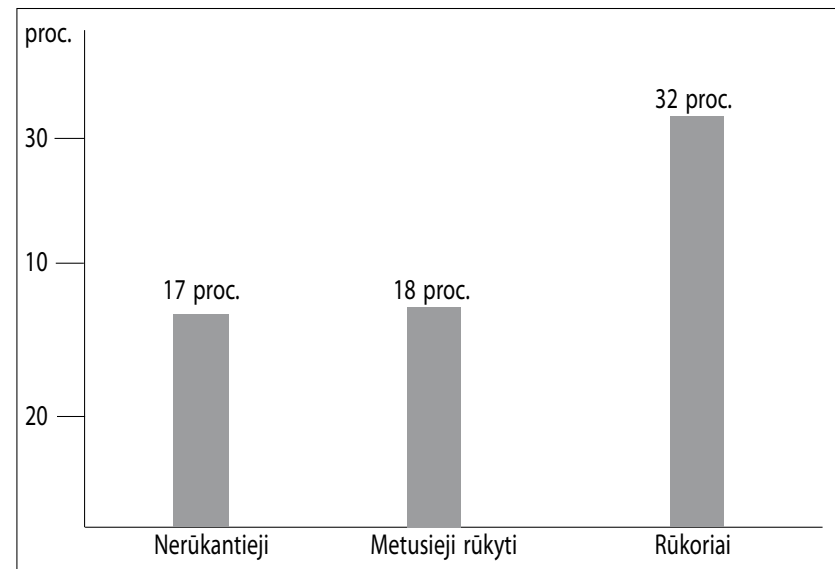

1 pav. KOSULIO PAPLITIMAS PENKIUOSE LIETUVOS RAJONUOSE

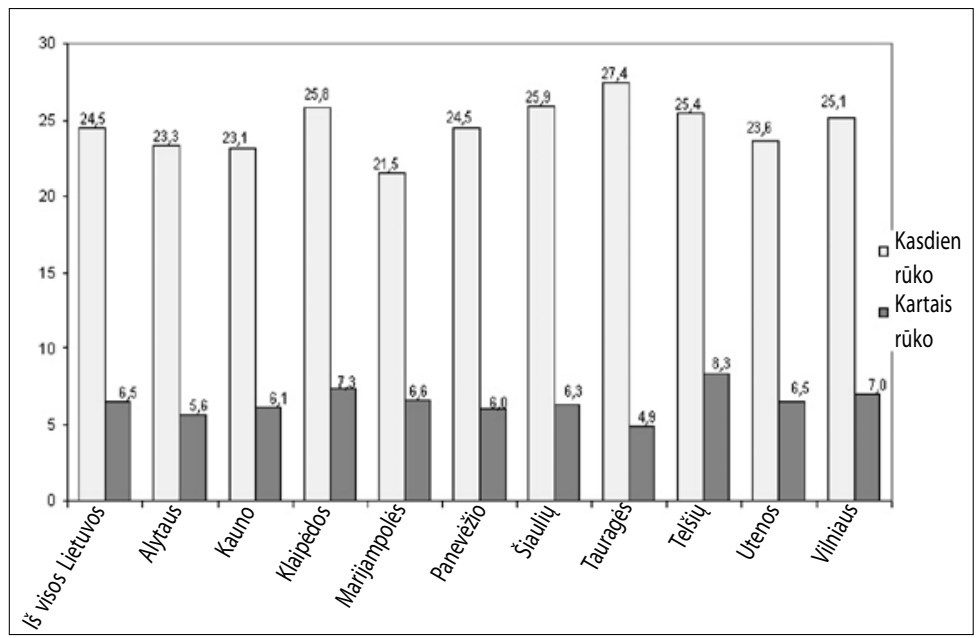

2 pav. RŪKYMO PAPLITIMAS LIETUVOS APSKRITYSE (LIETUVOS STATISTIKOS DEPARTAMENTO 2005 M. DUOMENYS) 
3 lentelè. KOSULIO DAŽNUMAS ATSIŽVELGIANT | RÜKYMO ĮROČIUS

\begin{tabular}{lllll}
\hline & & \multicolumn{3}{c}{ Dažnumas (proc.) } \\
\hline & $\begin{array}{l}\text { Nerūkan- } \\
\text { tieji }\end{array}$ & $\begin{array}{l}\text { Metę } \\
\text { rūkyti }\end{array}$ & $\begin{array}{l}\text { Rūkoriai } \\
(\leq 20 \text { cig./d. })\end{array}$ & $\begin{array}{l}\text { Rūkoriai } \\
(>20 \text { cig./d.) }\end{array}$ \\
\hline Naktinis kosulys & 27,0 & 27,4 & 33,5 & 39,6 \\
\hline $\begin{array}{l}\text { Neproduktyvus } \\
\text { kosulys }\end{array}$ & 8,2 & 6,7 & 12,4 & 18,7 \\
\hline $\begin{array}{l}\text { Produktyvus } \\
\text { kosulys }\end{array}$ & 6,1 & 6,7 & 12,3 & 26,8 \\
\hline
\end{tabular}

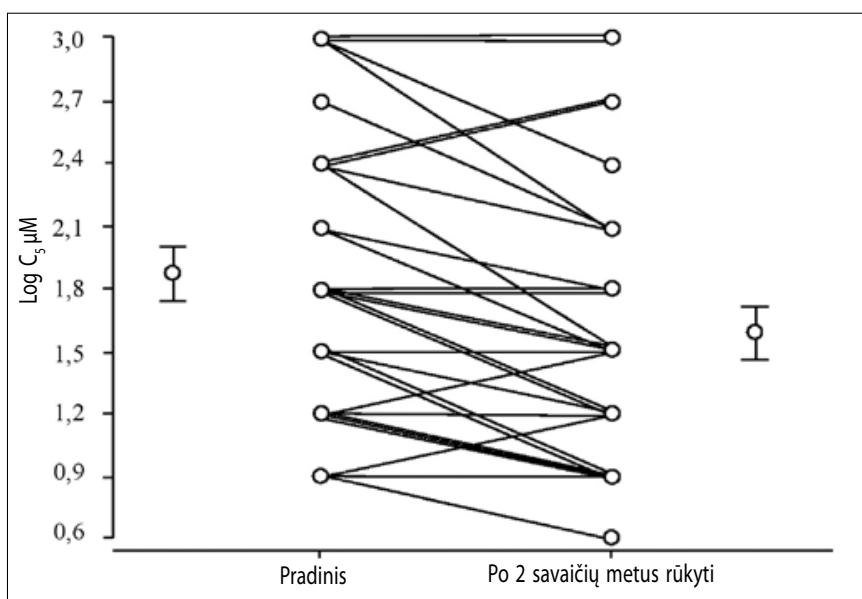

3 pav. KOSULIO REFLEKSO JAUTRUMO POKYČIAI SVEIKIEMS ASMENIMS NERÜKIUS DVI SAVAITES

Pradiniai rodikliai atspindi kosulio reflekso jautrumą, kol sveiki asmenys rūkè. Metus rūkyti per dvi savaites $\log C_{s}$ sumažéjo nuo $1,86 \pm 0,12 \mu \mathrm{M}$ iki 1,60 $\pm 0,12 \mu \mathrm{M}(\mathrm{p}=0,0004)$

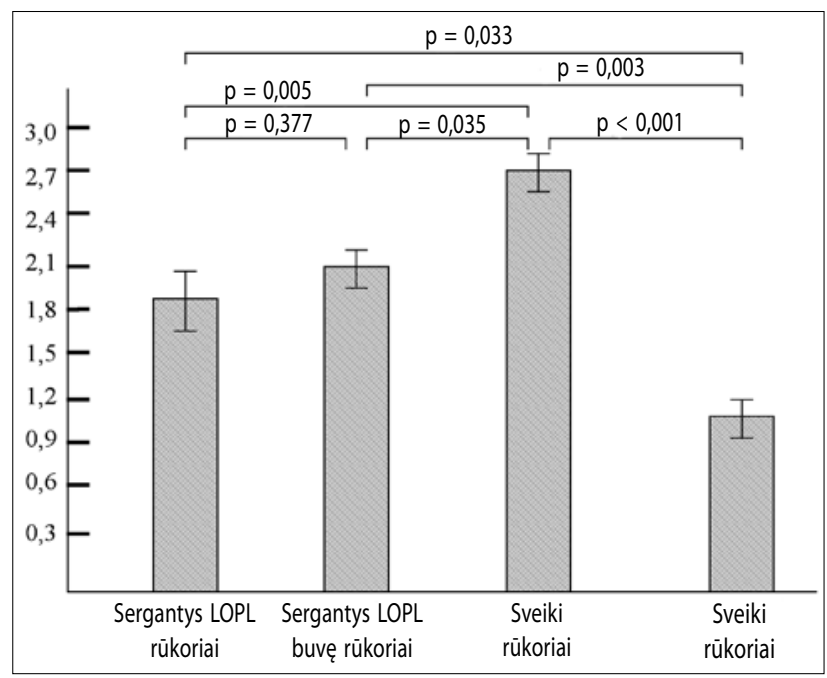

4 pav. KOSULIO REFLEKSO JAUTRUMAS (LOG $C_{5}$ ) TIRIAMŲJŲ GRUPÉSE

tusiems rūkyti LOPL ligoniams nesusilpnèja ar net sustiprejja, o neturintiems kvépavimo taku simptomų, susilpnèja ar normalizuojasi.

Tyrimų, kaip kinta kosulio reflekso jautrumas metus rūkyti, iki šiol nebuvo atlikta. Kauno medicinos universiteto Pulmonologijos ir imunologijos klinikoje, bendradarbiaujant su Niujorko A. Einšteino medicinos koledžu, pirmą kartą Lietuvoje atlikti tyrimai, kuriais vertintas metimo rūkyti poveikis sveikų ir sergančių
LOPL asmenu kosulio reflekso jautrumui.

Tyrimų rezultatai rodo, kad metusių rūkyti sveikų asmenų kosulio reflekso jautrumas padideja jau po pirmų dviejų savaičių (3 pav.).

Tiriamiesiems vèl pradèjus rūkyti, kosulio reflekso jautrumas vèl sumažèjo iki pradinio, kuris buvo prieš metant rūkyti.

Ištyrus sergančių LOPL rūkorių ir sergančių LOPL buvusių rūkorių kosulio reflekso jautrumą, nustatyta, kad jų kosulio reflekso jautrumas nesiskiria, tačiau yra mažesnis nei sveikų nerūkančių asmenų (4 pav.).

Taigi mūsų tyrimo rezultatai rodo, kad sveikų asmenų rūkymo sukeltas kosulio reflekso jautrumo sumažejjimas yra grịžtamas metus rūkyti. Sergančių LOPL rūkorių ir sergančių LOPL buvusių rūkorių kosulio reflekso jautrumas kapsaicinui nesiskiria. Tai sergant LOPL gali būti susiję su metus rūkyti besitęsiančiu kvẻpavimo taku uždegimu ir struktūriniais, cigarečių dūmų sukeltais, kvėpavimo takų pokyčiais.

Šie tyrimo duomenys pagrindžia ankstyvo metimo rūkymo naudą sveikiems asmenims.

\section{APIBENDRINIMAS}

Kosulys - vienas dažniausių nusiskundimų, dèl kurių pacientai kreipiasi i gydytoją, tačiau tyrimų, vertinančių kosulio reflekso jautrumą, dar atlikta labai nedaug. Rūkymas sumažina sveikų asmenų kosulio reflekso jautrumą, tačiau metus rūkyti jo jautrumas padidejja jau po dviejų savaičių. Tai pagrindžia ankstyvo metimo rūkyti naudą.

\section{COUGH AND SMOKING \\ KRISTINA STRAVINSKAITE \\ DEPARTMENT OF PULMONOLOGY AND IMMUNOLOGY KAUNAS UNIVERSITY OF MEDICINE}

Key words: cough, cough reflex sensitivity, smoking, COPD.

Summary. Cough is an effective defence mechanism. The prevalence of cough in Europe and USA is $9-33 \%$. Cough is the most common complain leading patients to consult with physician. Several billion dollars are spent for cough cure products of that for the most part are at best only partially effective. Cough is relevant medical and economical problem. Smoking is one of the most important and avoidable risk factor of respiratory disease. Smoking decreases cough reflex sensitivity in healthy subjects. The decrease of cough reflex sensitivity induced by cigarette smoking is reversible in healthy subjects after stopping smoking. Cough reflex sensitivity in COPD ex-smoker does not differ from COPD smokers.

\section{LITERATŪRA}

1. Chung FK. Prevalence, pathogenesis, and causes of chronic cough. Lancet 2008; 371:1364-74.

2. McCool FD. Global physiology and pathophysiology of cough. ACCP evidence-based clinical practice guidelines. Chest 2006; 129: S48-53.

3. Irwin RS. Introduction to the Diagnosis and Management of Cough: ACCP Evidence-Based Clinical Practice Guidelines. Chest 2006 129: S25-27.

4. Schramm CM. Current concepts of respiratory complications of neuromuscular disease in children. Curr Opin Pediatr 2000; 12:203-7.

5. Mosconi $\mathrm{P}$, Langer $\mathrm{M}$, Cigada $\mathrm{M}$, et al. Epidemiology and risk factors of pneumonia in critically ill patients: Intensive Care Unit Group for Infection Control. Eur J Epidemiol 1991; 7:320-7.

6. Irwin R, Boulet L-P, Cloutier MM, et al. Managing cough as a defense mechanism and as a symptom: a consensus panel report of the American College of Chest Physicians. Chest 1998; 114: S133-181. 